\title{
Pengaruh Kepatuhan Minum Obat Oral Anti Diabetik Terhadap Kadar Gula Darah Pada Pasien Diabetes Mellitus Tipe II
}

\author{
Selly Septi Fandinata, Rizky Darmawan \\ Akademi Farmasi Surabaya \\ Email : sellyfandinata@akfarsurabaya.ac.id
}

\begin{abstract}
ABSTRAK
Diabetes Melitus (DM) adalah penyakit metabolik yang ditandai dengan kadar glukosa darah tinggi (hiperglikemia) diakibatkan karena sekresi insulin, gangguan aktivitas insulin atau keduanya. Kepatuhan minum obat sangat penting untuk mencapai keberhasilan terapi pengobatan dan mencegah komplikasi. Keberhasilan terapi sangat dipengaruhi oleh kepatuhan pasien dalam minum obat. Tujuan dari penelitian ini adalah untuk mengetahui pengaruh kepatuhan terhadap obat oral anti-diabetes terhadap kadar gula darah pada pasien dengan diabetes mellitus tipe 2. Penelitian ini adalah kualitatif dengan metode analisis asosiatif dan metode pengambilan sampel menggunakan teknik convenience sampling. Hasil penelitian menggunakan analisis statistik uji korelasi Pearson (Product Momment) menunjukkan bahwa nilai-p $=0,048<0,05$ sehingga terdapat hubungan yang signifikan antara kepatuhan minum obat dengan perubahan kadar gula darah pasien dengan diabetes mellitus tipe 2. Hubungan yang signifikan diklasifikasikan dalam kategori lemah dengan nilai koefisien korelasi Pearson adalah $0,363<0,4$, koefisien korelasi positif sehingga hubungan antara kepatuhan minum obat dengan perubahan kadar gula darah tidak searah, artinya, semakin besar skor kepatuhan minum obat maka semakin besar pula selisih kadar gula darah pre dan post terapi.
\end{abstract}

Kata kunci: Diabebes Mellitus, efektivitas terapi, kepatuhan minum obat)

\begin{abstract}
Diabetes Mellitus (DM) is a metabolic disease characterized by high blood glucose levels (hyperglycemia) as a result reduce secretion insulin, disruption of insulin activity or both. Compliance medication is important to achieve the success of treatment therapy and prevent complications. The success of therapy is greatly influenced by the patient's compliance with taking medication. The purpose of this study was to determine the effect of adherence antidiabetic oral drugs on blood sugar levels in patients with type 2 diabetes mellitus. This study was qualitative with an associative analysis method and sampling method using convenience sampling technique. The results of the study using statistical analysis of Pearson correlation test (Product Momment) showed that the $p$-value $=0.048<0.05$ so that there is a significant relationship between medication adherence with changes in blood sugar levels of patients with type 2 diabetes mellitus. The significant relationship is classified in the category weak with Pearson correlation coefficient value is $0.363<0.4$, the correlation coefficient is positive so that the relationship between medication adherence with changes in blood sugar levels is unidirectional, meaning that the greater the medication adherence score, the greater the difference in blood sugar levels pre and post therapy.
\end{abstract}

Keywords : Diabebes Mellitus, Effectivity Therapy, Compliance Medication

http://ejournal.urindo.ac.id/index.php/kesehatan

Article History :

Sumbitted 18 Mei 2020, Accepted 29 Juni 2020, Published 30 Juni 2020 


\section{Jurnal Bidang IImu Kesehatan}

\section{PENDAHULUAN}

Diabetes Mellitus (DM) adalah penyakit metabolik yang di tandai dengan tingginya kadar glukosa darah (hyperglikemia) sebagai akibat dari kekurangan sekresi insulin, gangguan aktifitas insulina atau keduanya (Aini et al, 2011). DM terjadi bila insulin yang di hasilkan tidak cukup untuk mempertahankan gula darah dalam batas normal atau jika sel tubuh tidak mampu merespon dengan tepat sehingga akan muncul keluhan khas DM berupa poliuria, polidipsi, polifagia, penurunan berat badan,kelemahan, kesemutan, pandangan kabur dan disfungsi ereksi pada laki laki dan pruritus vulvae pada wanita (Ambarwati, 2012).

Kadar gula darah yang tidak terkontrol dapat menyebabkan berbagai komplikasi kerusakan organ seperti ginjal, mata, saraf, jantung, dan peningkatan resiko penyakit kardiovaskular (Aronson, 2007). Komplikasi ini yang menjadi penyebab kematian terbesar ke empat di dunia (Boyoh, 2015). Indonesia menempati peringkat ke empat setelah India, Cina, dan Amerika (Damyati, 2011). Jumlah penderita diabetes selalu meningkat setiap tahunnya, WHO memprediksi pada tahun 2030 jumlah pasien diabetes mencapai 21,3 juta (Dunham, 2011).

Pengobatan DM bertujuan untuk mencegah komplikasi dan meningkatkan kualitas hidup pasien (IDF, 2013). Pencegahan komplikasi dilakukan dengan cara menjaga kestabilan gula darah dengan pengobatan secara rutin seumur hidup karena DM merupakan penyakit seumur hidup yang tidak bisa disembuhkan secara permanen sehingga banyak pasien yang jenuh dan tidak patuh dalam pengobatan (Boyoh, 2015). Kepatuhan minum obat pada pasien diabetes melitus penting untuk mencapai tujuan pengobatan dan efektif untuk mencegah komplikasi pada penyakit diabetes melitus terutama bagi pasien yang harus mengkonsumsi obat dalam jangka waktu yang lama, bahkan seumur hidupnya (Boyoh, 2015).

Diabetes merupakan penyakit seumur hidup yang tidak bisa disembuhkan secara permanen sehingga banyak pasien yang jenuh dan tidak patuh dalam pengobatan yang menyebabkan tidak terkontrolnya kadar gula darah (Boyoh, 2015). Tingkat kepatuhan penderita dalam minum obat merupakan salah satu faktor yang menentukan keberhasilan terapi, terutama untuk penyakit kronis seperti diabetes melitus (Loghmani, 2005). Adapun yang menjadi faktor penghalang yang mempengaruhi kepatuhan pasien yaitu lamanya terapi, komplesitas rejimen, komunikasi yang kurang baik antara pasien dan tenaga kesehatan, kurangnya informasi, persepsi manfaat, keamanan, efek samping, biaya pengobatan dan faktor psikologis (Loghmani, 2005) (Pascal et al, 2012). 


\section{Jurnal Bidang Ilmu Kesehatan}

Menurut laporan World Health

Organization (WHO) pada tahun 2003, kepatuhan rata-rata pasien pada terapi jangka panjang terhadap penyakit kronis dinegara maju sebesar $50 \%$ dan dinegara berkembang diperkirakan akan lebih rendah. Sebuah meta analisis mengenai hubungan antara penggunaan obat terhadap kejadian mortalitas yang berasal dari 21 penelitian menunjukkan kepatuhan terhadap penggunaan obat berhubungan positif dengan hasil pengobatan (Pascal et al, 2012).

\section{Ketidakpatuhan pasien} meningkatkan resiko komplikasi dan bertambah parahnya penyakit yang diderita (Pratita, 2012). Berdasarkan laporan WHO tahun 2003, rata-rata kepatuhan pasien terapi jangka panjang pada penyakit kronis di negara maju mencapai 50\% sedangkan di negara berkembang lebih rendah. Keberhasilan terapi DM sangat dipengaruhi oleh kepatuhan pasien dalam menjalankan pengobatan. Keberhasilan terapi dapat dilihat dari penurunan kadar gula darah puasa menjadi antara 70 dan 130 mg/dL (Rasdianah dkk, 2016). Tujuan penelitian ini adalah untuk mengetahui pengaruh kepatuhan minum obat oral anti diabetik terhadap kadar gula darah pada pasien diabetes mellitus tipe II

\section{METODE}

Penelitian ini merupakan penelitian kualitatif dengan rancangan dengan metode analisa Asosiatif. Tujuan penelitian ini untuk mengetahui pengaruh kepatuhan minum obat oral anti diabetik terhadap kadar gula darah pada pasien diabetes mellitus tipe 2 . Penelitian ini dilakukan di Puskesmas Pandian Kabupaten Sumenep. Metode pengambilan sampel pada penelitian ini adalah menggunakan teknik convenience sampling. Variabel dalam penelitian ini adalah variable bebas adalah kepatuhan minum obat dan perubahan kadar gula darah pasien diabetes tipe II, sedangkan variable terikatnya adalah korelasi kepatuhan minum obat dengan perubahan kadar gula darah pasien diabetes tipe II.

Instrument kuisioner kepatuhan minum obat DM yang menggunakan 4 indikator kepatuhan (tepat dosis, tepat frekuensi, tepat interval, tepat waktu) telah diuji valid (nilai sig total $<0,05$ ) dan reliabilitas (KR-20=0,5). Responden dikatakan patuh apabila jawaban "Ya" pada 7 pertanyaan untuk wawancara sesuai dengan intruksi yang responden peroleh. Penelitian ini menggunakan analisa data statistik uji korelasi Pearson (Product Mommen)

\section{HASIL DAN PEMBAHASAN}

Pasien yang memenuhi kriteria inklusi dalam penelitian ini berjumlah 30 pasien rawat jalan yang mendapat terapi OAD. 
Jurnal Bidang Ilmu Kesehatan

Tabel 1. Karakteristik Pasien

\begin{tabular}{|c|c|c|}
\hline Demografi & Klarifikasi & $\begin{array}{c}\text { Jumlah } \\
\text { Pasien n (\%) }\end{array}$ \\
\hline Jenis & Perempuan & $18(60 \%)$ \\
\hline \multirow[t]{2}{*}{ Kelamin } & Laki-laki & 12 (40\%) \\
\hline & Total & 30 \\
\hline \multirow[t]{5}{*}{ Usia } & $36-45$ (Dewasa) & $1(3.3 \%)$ \\
\hline & $\begin{array}{c}46-55 \text { (Lansia } \\
\text { Awal) }\end{array}$ & $10(33.3 \%)$ \\
\hline & $\begin{array}{c}56-65 \text { (Lansia } \\
\text { Akhir) }\end{array}$ & $16(53.3 \%)$ \\
\hline & 65 - sampai atas & $3(10 \%)$ \\
\hline & Total & 30 \\
\hline \multirow[t]{5}{*}{ Penidikan } & SD & $9(30 \%)$ \\
\hline & SLTP & $6(10 \%)$ \\
\hline & SLTA & 11 (36.67\%) \\
\hline & SARJANA & 4 (13.3\%) \\
\hline & Total & 30 \\
\hline \multirow[t]{8}{*}{ Pekerjaan } & PNS & $1(3.3 \%)$ \\
\hline & Pensiun & $5(16,67 \%)$ \\
\hline & Swasta & 4 (13.3\%) \\
\hline & Wira Swasta & $8(26.67 \%)$ \\
\hline & $\begin{array}{c}\text { Ibu Rumah Tangga } \\
\text { (IRT) }\end{array}$ & $9(30 \%)$ \\
\hline & Supir & $2(6,67 \%)$ \\
\hline & Buruh Tani & $1(3.3 \%)$ \\
\hline & Total & 30 \\
\hline Lama & Baru & $10(33.3 \%)$ \\
\hline \multirow[t]{2}{*}{ Pasien } & Lama & $20(66,67 \%)$ \\
\hline & Total & 30 \\
\hline
\end{tabular}

Berdasarkan jenis kelamin, terdapat

18 pasien (60\%) berjenis kelamin perempuan dan 12 pasien (40\%) berjenis kelamin laki-laki. Dari penelitian ini diketahui bahwa sebagian besar pasien perempuan lebih banyak mengalami DM dari pada pasien laki-laki. Hal ini diduga karena perempuan cenderung mengalami resiko stress yang cukup meningkat, serta faktor yang dapat mempertinggi resiko DM tipe 2 yang dialami perempuan seperti riwayat kehamilan dan obesitas sehingga dapat memicu kenaikan kadar gula darah
(Santosa, 2011). Berdasarkan kriteria usia pada penelitian ini didapatkan bahwa penderita DM terbanyak adalah lansia akhir untuk pasien dengan rentang usia $56-65$ tahun yaitu sebanyak 16 pasien (53,3\%). Hal ini terutama disebabkan karena dengan bertambahnya usia, maka fungsi sel pankreas dan sekresi insulin akan berkurang, berkurangnya aktivitas fisik sehingga rentan terhadap berat badan berlebih. Resiko diabetes juga akan semakin meningkat pada usia lebih dari 45 tahun (Selly., Rizky, 2020).

Sedangkan status tingkat pendidikan pada penelitian ini didapatkan bahwa pasien mayoritas berada pada pendidikan tingkat SLTA sebanyak 11 pasien (36,67\%). Dalam penelitian ini didapatkan bahwa pengetahuan seseorang bisa mempengaruhi kepatuhan minum obat, karena semakin tinggi pendidikan seseorang maka semakin mudah untuk menerima informasi (Smeltzer et al, 2008). Dari demografi pekerjaan pasien mayoritas berprofesi sebagai ibu rumah tangga sebanyak 9 pasien (30\%). Ibu rumah tangga biasanya memiliki aktivitas fisik yang kurang. Berdasarkan penelitian Vaidya dan Kretek (2014), ibu rumah tangga memiliki olahraga yang tergolong rendah Rendahnya olahraga seseorang menjadi salah satu faktor risiko terjadinya diabetes melitus (Soegondo dkk, 2009).

Dari demografi lama pasien, didapatkan mayoritas pasien lama lebih 
banyak sebanyak 20 pasien (66,67\%). Berdasarkan penelitian sebelumnya bahwa tidak ada perbedaan signifikan kepatuhan minum obat antara pasien lama dan pasien baru diabetes mellitus tipe 2 (WHO, 2003). Penggunaan obat pada pasien rawat jalan dengan diagnosa DM dengan terapi obat oral antidiabetes di Puskesmas Pandian Sumenep di tinjau dari terapi OAD yang diperoleh dapat dilihat pada tabel berikut :

Tabel 2. Penggunaan obat pada Pasien dengan diagnosa DM

\begin{tabular}{cc}
\hline Terapi OAD & $\begin{array}{c}\text { Jumlah Pasien } \\
\text { n (\%) }\end{array}$ \\
\hline Glibenclamide & $5(16,67 \%)$ \\
Glimepiride & $14(46,67 \%)$ \\
Glikazide & $4(13,33 \%)$ \\
Metformin & $7(23,33 \%)$ \\
Total & $30(100 \%)$ \\
\hline
\end{tabular}

Kepatuhan pengobatan adalah kesesuaian pasien terhadap anjuran atas medikasi yang telah diresepkan yang terkait dengan waktu, dosis, dan frekuensi. Hubungan antara pasien, penyedia layanan kesehatan, dan dukungan social merupakan faktor penentu yang mendasar dan terkait dengan kepatuhan minum obat. Tingkat kepatuhan merupakan salah satu hal yang berperan penting dalam pengobatan penyakit yang bersifat kronik (Widiasworo dkk, 2015). Penyebab rendahnya kepatuhan yang sering muncul kebanyakan pasien lupa, tidak mematuhi pengobatan sesuai dengan petunjuk dokter, dan kesalahan pembacaan etiket (Widyasari, 2017).
Tabel 3. Kepatuhan Penggunaan OAD terhadap Masing-Masing Variabel Kepatuhan

\begin{tabular}{ccc}
\hline Variabel Kepatuhan & Patuh & $\begin{array}{l}\text { Tidak } \\
\text { Patuh }\end{array}$ \\
\hline
\end{tabular}

\begin{tabular}{|c|c|c|c|}
\hline \multirow{4}{*}{$\begin{array}{l}\text { Tepat } \\
\text { dosis }\end{array}$} & \multicolumn{3}{|l|}{ Pertanyaan } \\
\hline & 1 & 27 (90\%) & $3(10 \%)$ \\
\hline & \multicolumn{3}{|l|}{ Pertanyaan } \\
\hline & 2 & $27(90 \%)$ & $3(10 \%)$ \\
\hline \multicolumn{2}{|c|}{ Total \% } & $90 \%$ & $10 \%$ \\
\hline Tepat & & 28 & 2 \\
\hline frekuensi & $\begin{array}{c}\text { Pertanyaan } \\
3\end{array}$ & (93.3\%) & (6.67\%) \\
\hline \multicolumn{2}{|c|}{ Total \% } & $93.3 \%$ & $6.67 \%$ \\
\hline $\begin{array}{l}\text { Tepat } \\
\text { waktu }\end{array}$ & $\begin{array}{c}\text { Pertanyaan } \\
4\end{array}$ & $\begin{array}{c}23 \\
(76,67 \%)\end{array}$ & $\begin{array}{c}7 \\
(23,33 \%)\end{array}$ \\
\hline \multicolumn{4}{|c|}{ Pertanyaan } \\
\hline & 5 & $18(60 \%)$ & $12(40 \%)$ \\
\hline \multicolumn{2}{|c|}{ Total \% } & $68.34 \%$ & $31.66 \%$ \\
\hline $\begin{array}{c}\text { Tepat } \\
\text { interval }\end{array}$ & $\begin{array}{c}\text { Pertanyaan } \\
6\end{array}$ & $\begin{array}{c}17 \\
(56,67 \%)\end{array}$ & $\begin{array}{c}13 \\
(43,33 \%)\end{array}$ \\
\hline & $\begin{array}{c}\text { Pertanyaan } \\
7\end{array}$ & $\begin{array}{c}17 \\
(56,67 \%)\end{array}$ & $\begin{array}{c}13 \\
(43,33 \%)\end{array}$ \\
\hline & al \% & $56,67 \%$ & $43,33 \%$ \\
\hline
\end{tabular}

Dalam penelitian ini kepatuhan pasien diukur dengan menggunakan 4 variabel kepatuhan, yaitu tepat dosis, tepat frekuensi, tepat waktu dan tepat interval. Pada variabel pertama yaitu tepat dosis. Indikator dari variabel tepat dosis adalah dosis obat untuk sekali minum. Tepat dosis akan membantu terkontrolnya gula darah pasien. Pasien yang teratur minum obat sesuai dosis yang diberikan oleh dokter, maka gula darah akan terkontrol dengan baik, sebaliknya jika pasien minum obat tidak sesuai dengan dosis yang diberikan oleh dokter, baik itu 
melebihi atau mengurangi dosis maka akan mengakibatkan gula darak menjadi naik turun (Widyasari, 2017). Dari hasil penelitian berdasarkan variabel kepatuhan tepat dosis diperoleh $90 \%$ patuh dan $10 \%$ tidak patuh. Pengurangan dosis ini mengakibatkan gula darah tidak terkontrol .

Pada variabel kedua yaitu tepat frekuensi. Indikator dari variabel tepat frekuensi adalah penggunaan obat dalam sehari. Beberapa pasien lebih senang pada pengobatan dengan frekuensi yang jarang, misalnya saja penggunaan satu kali sehari. Hal ini disebabkan pasien akan lebih mudah mengikuti regimen dosis dari dokter. data penelitian berdasarkan variable frekuensi bahwa hasil penelitian berdasarkan frekuensi menunjukkan bahwa 93.3\% patuh dan $6,67 \%$ tidak patuh. Pasien yang patuh merupakan pasien yang mendapat terapi glibenklamid, glimepirid atau glikazid yang frekuensi penggunaannya sehari satu kali sedangkan pasien yang tidak patuh merupakan pasien yang mendapat terapi metformin dengan frekuensi sehari tiga kali, sehingga kebanyakan pasien lupa untuk minum obat.

Pada variabel ketiga yaitu tepat waktu. Indikator dari variabel tepat waktu berdasarkan jenis OAD yang didapat, misalnya glibenklamid, glimepirid dan glikazid diminum sebelum makan, metformin diminum sesudah atau saat makan. Pada variabel ini juga dilihat jarak antara minum obat dan makan. Beberapa pasien ada yang lupa makan setelah minum obat hal ini disebabkan pasien takut gula darahnya naik. Dari hasil penelitian berdasarkan variabel kepatuhan tepat waktu diperoleh $68.34 \%$ patuh dan $31.66 \%$ tidak patuh. Informasi yang didapatkan dari pasien bahwa pasien lupa makan setelah minum glibenklamid, glikazide atau glimepiride.

Pada variabel keempat yaitu tepat interval. Indikator dari variabel tepat interval adalah jarak waktu penggunaan obat antara obat yang digunakan hari ini dengan hari sebelumnya. Interval penggunaan obat berpengaruh pada efektivitas obat yaitu selisih antara obat mulai bekerja sampai kadar obat dalam darah menurun sehingga efek nya mulai berkurang (Widyasari, 2017). Dari hasil penelitian berdasarkan variabel kepatuhan tepat interval diperoleh $(56,67 \%)$ patuh dan $43,33 \%$ tidak patuh. Pada pasien yang menggunakan glibenklamid, glimepirid atau glikazid seringkali menggunakan obat tidak pada jam yang sama. Hal ini dipengaruhi aktivitas yang padat atau lupa minum obat. Pada beberapa pasien langsung minum obat ketika ingat. Sedangkan untuk pasien yang menggunakian metformin menyesuaikan jadwal makan pasien.

$$
\text { Keberhasilan terapi pada pasien }
$$
diabetes mellitus menunjukkan adanya peningkatan kualitas hidup pasien serta terhindar dari adanya penyakit komplikasi. Keberhasilan terapi 


\section{Jurnal Bidang IImu Kesehatan}

dipengaruhi oleh adanya kepatuhan, motivasi, serta dukungan keluarga.

Keberhasilan terapi diabetes mellitus dapat ditingkatkan dengan cara mengatur diet, memonitor kadar gula darah, merawat kebersihan kaki dan porsi olah raga (Wijaya dkk, 2015).

Tabel 4. Perubahan Kadar Gula Darah

\begin{tabular}{ccc}
\hline $\begin{array}{c}\text { Perubahan } \\
\text { Kadar Gula Darah }\end{array}$ & Jumlah & $\%$ \\
\hline Turun & 25 & 83.33 \\
Tetap & 0 & 0 \\
Naik & 5 & 16.67 \\
Total & 30 & 100 \\
\hline
\end{tabular}

Data pasien diabetes tipe II diuji normalitas menggunakan uji Shapiro Wilk, hasilnya menunjukkaan nilai $p$-value untuk kepatuhan minum obat dan perubahan kadar gula darah masing-masing adalah $0,00<0,05$ dan 0,047<0,05. Ini artinya data kepatuhan minum obat dan perubahan kadar gula darah adalah terdistribusi normal. Dengan demikian analisa data pada penelitian ini menggunakan uji korelasi Pearson (Product Momment). menunjukkan nilai $p$-value $=0,048<0,05$. Dengan demikian, sehingga terdapat hubungan signifikan antara kepatuhan minum obat dengan perubahan kadar gula darah pasien diabetes mellitus tipe 2 . Hubungan tersebut tergolong dalam kategori lemah karena koefisien korelasi pearson adalah 0,363 < 0,4 .

\section{SIMPULAN}

Berdasarkan beberapa pendapat para Keberhasilan terapi dilihat dari perubahan kadar gula darah menunjukkan bahwa mayoritas kadar gula darah turun dengan jumlah 25 pasien (83.33\%). Data pasien diabetes tipe II diuji normalitas menggunakan uji Shapiro Wilk, hasilnya menunjukkaan nilai p-value untuk kepatuhan minum obat dan perubahan kadar gula darah masing-masing adalah $0,00<0,05$ dan 0,047<0,05. Ini artinya data kepatuhan minum obat dan perubahan kadar gula darah adalah terdistribusi normal. Dengan demikian analisa data pada penelitian ini menggunakan uji korelasi Pearson (Product Momment). menunjukkan nilai $p$-value $=0,048<0,05$ Dengan demikian, sehingga terdapat hubungan signifikan antara kepatuhan minum obat dengan perubahan kadar gula darah pasien diabetes mellitus tipe 2 . Hubungan tersebut tergolong dalam kategori lemah karena koefisien korelasi pearson adalah 0,363 < 0,4 . Disamping itu koefisien korelasi tersebut bernilai positif sehingga hubungan antara kepatuhan minum obat dengan perubahan kadar gula darah bersifat searah, artinya semakin besar skor kepatuhan minum obat maka semakin besar pula selisih kadar gula darah pre dan post terapi. 


\section{DAFTAR PUSTAKA}

Aini, N., Widayati, F., \& Yusuf, A.H., 2011, Upaya Meningkatkan Perilaku Pasien Dalam Tatalaksana Diabetes Mellitus dengan Pendekatan Teori Model Behavioral Syste DOROTHY E. JOHNSON, Jurnal Ners, 6(1), 1-10

Ambarwati, W.N., 2012, Konseling Pencegahan dan Penatalaksanaan Penderita Diabetes Mellitus, Publikasi ilmiah, Universitas Muhammadiyah Surakarta [7] Aronson, J.K., 2007. Compliance, concordance, adherence. British Journal of Clinical Pharmacology, 63(4), pp.383-384.

Aronson, J.K., 2007. Compliance, concordance, adherence. British Journal of Clinical Pharmacology, 63(4), pp.383-384.

Boyoh. E.M., Kaawoan.A., Bidjuni.H., 2015. Hubungan Pengetahuan Dengan Kepatuhan Minum Obat Pada Pasien Diabetes Melitus Tipe 2 Di Poliklinik Endokrin Rumah Sakit Prof.DR.R.D.Kandou Manado. Jurnal keperawatan (e-Kp) vol. 3, no.3, p. 16.

Damyati, V., 2011, Diabetes, RI Urutan Empat Terbesar. http://www.jurnas.com/halaman/9/2 011-11-14/188943 (diakses tanggal 18 Desember 2019)

Dunham, P.J. \& Karkula, J.M., 2012. Effects of a Pharmacy Care Program on
Adherence and Outcomes. The American Journal of Pharmacy Benefits, (February), pp.8-14. Available at: www.ajpblive.com.

International Diabetes Federation (2013).

Diabetes Atlas 6th ed. Belgium

Loghmani, E., 2005, Guidelines for Adolescent Nutrition Services: Chapter 14. Diabetes Mellitis: Type 1 and Type 2, School of Publik Healty

Pascal, I.G., Ofoedu, J.N., Uchenna, N.P., Nkwa, A.A, \& Uchamma, G.E., 2012, Blood Glucose Control and Medication Adherence Among Adult Type 2 Diabetic Nigerians Attending a Primary Care Clinic in Under-resourced Environment of Eastern Nigeria, North Am J Med Sci, 4, 310-5

Pratita, N.D., 2012. Hubungan Dukungan Pasangan dan Health Locus of Control dengan Kepatuhan dalam Menjalani Proses Pengobatan pada Penderita Diabetes Melitus Tipe $2 . \quad J u r n a l$ Ilmiah Mahasiswa Universitas Surabaya, 1(1).

Rasdianah. N, Martodiharjo. S, Andayani.T.M, Hakim, L. 2016. Gambaran Kepatuhan Pengobatan Pasien Diabetes Mellitus Tipe 2 di Puskesmas Vol.5.No.4,p 249-251. Santosa, M., 2011, Pengenalan Penyakit DM \& Penanganannya Dewasa ini, http://www.pbpapdi.org/papdi.php?p 
Jurnal Bidang Ilmu Kesehatan

b=detil_berita\&kd_berita $=87$ (diakses

tanggal 15 Januari 2020)

Selly., Rizky, 2020. Perbedaan Kepatuhan

Minum Obat Pada Pasien Yang Baru

Terdiagnosa dan Sudah Lama

Terdiagnosa Penyakit Diabetes

Melitus Tipe 2. Jurnal Manuntung, vol. 6 edisi 1

Smeltzer S.C \& Bare, Brunner \& Suddarth.

2008. Keperawatan Medikal Bedah.

(terjemahan) Edisi 8 Volume 2 Ahli

Bahasa H.Y Kuncura, Andry Hartono,

Monica Ester, Yasmin Asih. Jakarta :

EGC

Soegondo, S., Soewondo P; \& Subekti 2009.

Penatalaksanaan Diabetes Mellitus

Terpadu. Jakarta: Fakultas Kedokteran

Unversitas Indonesia

WHO, 2003. Adherence to Long- Term

Therapies: Evidence for Action.
Widiasworo, F.B., Wijaya, N., Ratna, E., Sulistyarini, A., 2015. Profil Kepatuhan Pasien Puskesmas Candi Sidoarjo Dalam Penggunaan Anti Diabtes Oral.Jurnal Farmasi Komunitas.Vol.2, No.1, p.5-11.

Widyasari, N. 2017. Hubungan Karakteristik Responden Dengan Resiko Diabetes Melitus dan Dislipidemia Kelurahan Tanah Kalikedinding.Jurnal Berkala Epidemiologi. Vol. 5, No.1, p 130-141.

Wijaya, N., Faturrohmah, A., Agustin, W., et al. 2015. Profil Kepatuhan Pasien Diabetes Melitus Puskesmas Wilayah Surabaya Timur Dalam Menggunakan Obat Dengan Metode Pill Count. Jurnal Farmasi Komunitas.Vol.2, No.1, P.1822.Baro, 